\title{
PENOLAKAN AJAKAN DALAM MASYARAKAT MELAYU DAN JEPUN: SATU KAJIAN SOSIOPRAGMATIK
}

\section{(Declining an Invitation in Malay and Japanese Societies:}

\section{A Sociopragmatic Study)}

\section{Natsue Hieda*}

hiedanatsue@gmail.com

Nor Hashimah Jalaluddin

shima@ukm.edu.my

Mohammad Fadzeli Jaafar

fadzeli@ukm.edu.my

Pusat Kajian Bahasa dan Linguistik, Fakulti Sains Sosial dan Kemanusiaan, Universiti Kebangsaan Malaysia

Pengarang koresponden (Corresponding author): *

Sila rujuk: Natsue Hieda, Nor Hashimah Jalaluddin \& Mohammad Fadzeli Jaafar. (2022). Penolakan ajakan dalam masyarakat Melayu dan Jepun: Satu kajian sosiopragmatik. Melayu: Jurnal Antarabangsa Dunia Melayu, 15(1), 69-90. http:// doi.org. 10.37052/jm.15(1)no4

\begin{tabular}{|lllll}
\hline $\begin{array}{l}\text { Peroleh: } \\
\text { Received: 27/5/2021 }\end{array}$ & $\begin{array}{l}\text { Semakan: } \\
\text { Revised }\end{array}$ & 23/9/2021 & $\begin{array}{l}\text { Terima: } \\
\text { Accepted: 4/11/2021 }\end{array}$ & $\begin{array}{l}\text { Terbit dalam talian: } \\
\text { Published online: }\end{array}$
\end{tabular}

\begin{abstract}
Abstrak
Pemilihan lakuan komunikasi berkait rapat dengan pemikiran, nilai dan kepercayaan dalam sesuatu masyarakat. Objektif kajian ini adalah untuk menjelaskan strategi penolakan ajakan yang digunakan oleh penutur asli bahasa Melayu (MNS) dan penutur asli bahasa Jepun (JNS) terhadap dua situasi yang berlainan, iaitu "membelibelah" dan "mengadakan parti". Kaedah pengutipan data yang diterapkan dalam
\end{abstract}


kajian ini ialah kaedah lakonan terbuka menerusi perkhidmatan rangkaian sosial dengan melibatkan 20 orang informan bagi setiap kumpulan MNS dan JNS. Kajian ini membuat perbandingan terhadap kekerapan penggunaan formula semantik dalam kedua-dua konteks bahasa ibunda mahupun konteks antara budaya. Hasil kajian menunjukkan bahawa MNS lebih menitikberatkan "kesantunan positif", manakala JNS lebih mementingkan "kesantunan negatif” bagi kedua-dua situasi dalam konteks bahasa ibunda apabila "niat penolakan" dikemukakan. Sementara itu, bagi penolakan untuk "mengadakan parti" dalam konteks bahasa ibunda, MNS menunjukkan "minat" secara tidak langsung dengan kerap menggunakan "kata seru positif", manakala JNS menunjukkan "minat" secara lebih eksplisit dengan kerap menyatakan \{reaksi positif\} dan \{kesedihan\}. Bagi konteks antara budaya pula, pendekatan MNS telah berubah untuk menitikberatkan "kesantunan negatif" serta menunjukkan "minat" secara terus terang mengikut norma dalam bahasa sasaran. Kajian ini telah menonjolkan pengaruh "situasi" serta daya keterbukaan dalam kalangan MNS yang mengelakkan konflik.

Kata kunci: Sosiopragmatik, penolakan ajakan, lakonan terbuka, formula semantik, komunikasi antara budaya, kesantunan

\begin{abstract}
The choice of communication behaviour is closely related to the thoughts, values and beliefs in a society. The objective of this study is to elaborate on the refusal strategies in invitation used by native speakers of Malay (MNSs) and Japanese (JNSS) towards two different situations, namely "shopping" and "holding a party". The data collection method utilised in this study was open role-play through a social networking service by involving 20 informants in each group. The study made comparisons of the frequency of semantic formula usage in both native and intercultural contexts. The results showed that the MNSs focused more on "positive politeness", while the JNSs prioritised "negative politeness" for both situations in native contexts when the "refusal intention" was presented. Meanwhile, for the refusal to "hold a party" in native contexts, the MNSs showed indirect "interest" by frequently using "positive interjection", while the JNSs showed more explicit "interest" by frequently stating \{positive opinion\} and \{disappointment\}. Regarding the intercultural contexts, the MNSs altered their approach to enhance "negative politeness" and show more direct "interest" in response to the target language norms. This study has highlighted the influence of the "situation" and the power of openness among the MNSs who avoid conflict.
\end{abstract}

Keywords: Sociopragmatic, declining an invitation, open role-play, semantic formula, intercultural communication, politeness 


\section{PENGENALAN}

Pragmatik merupakan salah satu cabang linguistik yang mengkaji bahasa dari sudut pandangan pengguna, terutama pemilihan yang dibuat, kekangan yang dihadapi ketika menggunakan bahasa dalam interaksi sosial, dan kesan penggunaan bahasa terhadap peserta lain dalam lakuan komunikasi (Kamus Linguistik, 1997). Leech (1983) membezakan pragmatik kepada dua jenis, iaitu pragmalinguistik dan sosiopragmatik. Pragmalinguistik lebih berkait rapat dengan tatabahasa, manakala sosiopragmatik lebih berhubung dengan sosiologi. Sosiopragmatik memperhatikan perspektif sosial yang mendasari tafsiran dan persembahan interlokutor terhadap lakuan komunikasi (Kasper \& Rose, 2001).

Sebagai contoh lakuan komunikasi yang berbeza dari sudut sosiopragmatik, penutur asli bahasa Inggeris di Amerika Syarikat lebih cenderung untuk menyatakan \{penghargaan\} apabila mereka diberikan pujian, manakala penutur asli bahasa Jepun lebih cenderung untuk menafikan pujian dengan merendahkan diri (Shimizu, 2009). Perbezaan pemilihan lakuan komunikasi tersebut berkait rapat dengan pemikiran, nilai dan kepercayaan dalam sesuatu masyarakat. Perbandingan antara dua atau lebih bahasa yang berlainan berkesan untuk menonjolkan ciri lakuan komunikasi dalam sesuatu masyarakat secara lebih terperinci kerana perbandingan tersebut membantu pengkaji untuk mengenali perkara yang tidak disedari dalam sesuatu budaya.

Kajian ini memberikan perhatian kepada lakuan komunikasi "penolakan ajakan". "Ajakan" boleh didefinisikan sebagai "pelawaan atau jemputan untuk turut serta melakukan sesuatu" (Kamus Dewan Edisi Keempat, 2007). Ajakan dilakukan dalam kehidupan seharian untuk membina, mengekalkan serta memperkuat hubungan sesama manusia agar lebih mesra dan baik. Antara dua keputusan, iaitu sama ada penerimaan atau penolakan terhadap ajakan, penolakan merupakan lakuan komunikasi yang lebih kompleks dan sukar dilaksanakan kerana tidak dapat memenuhi kehendak pengajak. Oleh yang demikian, penolakan ajakan memerlukan pelbagai langkah untuk memperbaik ketidakseimbangan yang terjadi antara interlokutor (Fujimori, 1995).

Sehubungan itu, kajian tentang penolakan ajakan telah dijalankan secara meluas dan aktif di dalam dan di luar negara Malaysia mahupun Jepun. Kajian tersebut semakin bervariasi dari segi bahasa yang dibandingkan, kaedah pengumpulan data serta sasaran yang dianalisis.

Namun demikian, kajian tentang penolakan ajakan sebelum kajian ini lebih membincangkan aspek "hubungan interpersonal" dari perspektif "jarak sosial" dan "kuasa relatif". Dari segi "jarak sosial”, perbezaan lakuan komunikasi antara orang yang rapat dengan orang yang tidak rapat. Dari sudut "kuasa relatif" pula, perbezaan 
lakuan komunikasi antara orang atasan, orang setaraf dengan orang bawahan dijelaskan.

Sebaliknya, perbezaan lakuan komunikasi antara "situasi" yang berlainan kurang diperhatikan dalam kajian lepas. Ajakan dilakukan dalam kehidupan seharian untuk pelbagai tindakan bersama antara interlokutor, seperti "pergi makan", "menonton wayang", "bermain badminton", "berjalan-jalan" dan sebagainya. Walaupun lakuan ajakan dijalankan antara interlokutor yang sama, strategi penolakan dijangka berbeza mengikut "situasi" ajakan yang berlainan.

Sebagai tambahan, kajian tentang bagaimana orang Malaysia menggunakan bahasa Jepun sebagai bahasa kedua masih kurang dilakukan sebelum ini walaupun Malaysia mempunyai bilangan pelajar bahasa Jepun kesepuluh terbesar di dunia (The Japan Foundation, 2020). Kerajaan Malaysia juga telah menghantar lebih daripada 16000 pelajar atau pelatih ke negara Jepun bersandarkan Dasar Pandang ke Timur. Dasar tersebut telah dilancarkan oleh Tun Dr. Mahathir Mohamad untuk mempelajari etika kerja, cara pengurusan, disiplin dan dedikasi dari negara di Asia Timur itu (Embassy of Japan in Malaysia, 2021).

Sehubungan itu, kajian ini memberikan tumpuan pada strategi penolakan ajakan antara penutur asli bahasa Melayu (selepas ini disebut sebagai MNS) dengan penutur asli bahasa Jepun (selepas ini disebut sebagai JNS). Perbandingan antara dua kumpulan tersebut dilakukan dalam dua "situasi", iaitu situasi (a) "membeli-belah" dan situasi (b) "mengadakan parti". Perbandingan turut dibuat dalam dua konteks, iaitu konteks bahasa ibunda (konteks antara penutur asli satu sama lain) dan konteks antara budaya (konteks antara MNS dengan JNS dalam bahasa Jepun). Seterusnya, kajian ini akan membincangkan faktor budaya Melayu dan Jepun yang menghasilkan persamaan dan perbezaan terhadap strategi penolakan ajakan.

\section{KAJIAN LITERATUR}

Bahagian ini memberikan tumpuan pada perbezaan lakuan komunikasi "ajakan" yang dipengaruhi oleh perbezaan "situasi", bukan "hubungan interpersonal".

Sebagai permulaan, Tsutsui (2002) memperhatikan struktur wacana ajakan mengikut "situasi". Menurut beliau, wacana ajakan yang paling pendek dan ringkas seperti [ajakan]-[penerimaan] boleh direalisasikan apabila ajakan yang sama telah dilakukan berulang kali serta tindakan boleh diambil terus selepas ajakan. Misalnya, ajakan untuk pergi minum petang bersama-sama rakan sekerja pada waktu rehat (Contoh: Pengajak "Jom pergi minum", Penerima "OK, jom”) merupakan wacana yang paling ringkas. Sebaliknya, wacana ajakan yang belum dikongsi kandungannya antara interlokutor menjadi lebih panjang dan kompleks dengan disertakan bahagian 
yang memastikan prasyarat (masa, kemampuan, minat dan sebagainya) atau bahagian yang membincangkan masa dan tempat temu janji.

Kawaguchi et al. (2002) menambah pandangan mereka terhadap wacana ajakan, iaitu mengikut "situasi”. Sekiranya kandungan ajakan telah dikongsi antara interlokutor, atau pengajak berwenang untuk menetapkan tindakan bersama, situasi tersebut bertahap "kelaziman ajakan" yang tinggi dan ekspresi "-mashoo" (Let's) digunakan dalam bahasa Jepun. Sementara itu, bagi situasi ajakan yang bertahap "kelaziman ajakan" yang rendah, ekspresi "-masen ka" (Won't you) dipilih serta wacana menjadi lebih kompleks dan panjang.

Laohaburanakit (1995) pula menganalisis wacana ajakan dengan menumpukan "faktor masa atau kemampuan" dan "keperluan penyertaan". Dari sudut "faktor masa atau kemampuan", keadaan penolak dapat difahami secara sepenuhnya oleh pengajak sekiranya diterangkan alasan atas faktor masa atau kemampuan yang jujur. Sebaliknya, penolakan atas faktor yang lain, seperti tidak berminat atau tidak menyukai, memerlukan strategi yang berlainan untuk memberitahu penolakan kepada pengajak dengan memberikan \{permintaan maklumat\} atau \{kesukaran\} secara perlahan-lahan. Dari sudut "keperluan penyertaan" pula, semakin tinggi keperluan penyertaan penolak, semakin sukar untuk menyatakan \{keputusan\} secara terus terang kepada pengajak. Liu (2015) mengkaji tentang reaksi informan terhadap ajakan yang diminati dan ajakan yang tidak diminati. Oleh sebab keputusan bergantung pada informan, informan beliau cenderung untuk menerima ajakan yang diminati serta menolak ajakan yang tidak diminatinya. Beliau menerangkan bahawa JNS lebih bersikap kerjasama dengan menyatakan \{reaksi positif\} terhadap maklumat yang diberikan bagi ajakan yang diminati, sedangkan informan Cina lebih proaktif untuk menjaga perasaan pengajak dengan kerap memberi \{permintaan maklumat\} yang menunjukkan minat terhadap kandungan ajakan. Bagi ajakan yang tidak diminati pula, kedua-dua kumpulan tersebut menunjukkan \{pemberian maklumat\} atau \{pendapat\} yang negatif sebagai isyarat bahawa mereka tidak berminat. Namun begitu, perbezaan didapati sebagaimana JNS tetap bersikap kerjasama dengan lebih menunjukkan \{kefahaman\}, sedangkan informan Cina memberi juga \{permintaan maklumat\} bagi ajakan yang tidak diminati supaya dapat menangguhkan \{keputusan\} sementara waktu serta mengambil masa untuk berfikir.

Huang (2015) memperhatikan strategi pengajak dalam bahagian penutup selepas ajakan diterima dengan membandingkan dua situasi yang berbeza bebannya. Menurut beliau, beban tindakan merupakan beban psikologi terhadap kedua-dua pihak yang mengajak dan diajak dari segi masa, perjalanan, kewangan dan sebagainya. Sekiranya pihak yang diajak berada dalam keadaan yang sibuk, beban tindakan dari segi "masa" 
akan meningkat walaupun ajakan yang sama dilakukan antara interlokutor yang sama. Beliau berpandangan bahawa pertimbangan untuk perasaan lawan tutur meningkat bagi situasi yang lebih membebankan dalam data JNS. Sementara itu, ujaran "saya akan belanja" ditemui bagi situasi untuk "pergi makan", manakala ujaran tersebut tidak ditemui bagi situasi untuk "pergi memetik buah ceri" dalam data bahasa Cina disebabkan oleh perbezaan "situasi" ajakan itu sendiri.

Nakagaki $(2014,2015)$ membuat perbandingan dua situasi, iaitu ajakan untuk pergi makan tengah hari yang "terus dilakukan" selepas ajakan serta ajakan untuk pergi makan malam dua hari kemudian yang "tidak terus dilakukan" selepas ajakan. Kedua-duanya lebih membincangkan persamaan antara dua situasi tersebut, iaitu \{sebab\} yang dinyatakan oleh JNS lebih ringkas dan terus diterima oleh pengajak JNS, manakala penutur bahasa Swahili lebih memberi \{keputusan\} dan \{sebab\} berulang kali oleh sebab ajakan semula yang kerap dilakukan. Informan JNS juga lebih memberi \{pengekalan hubungan\} dalam bahagian penutup selepas penolakan diterima, manakala penutur bahasa Swahili memberi \{pengekalan hubungan\} sebelum penolakan diterima dengan meminta persetujuan lawan tutur. Perbezaan antara dua situasi tersebut hanya dinyatakan dari sudut lakuan pengajak dalam bahagian permulaan, dan tiada penghuraian dari perspektif penolak.

Seperti yang ditunjukkan di atas, terdapat beberapa kajian yang menghuraikan perbezaan "situasi”" terhadap wacana ajakan. Namun demikian, strategi penolakan ajakan masih kurang dijelaskan dari segi perbezaan "situasi”. Setahu pengkaji, perbincangan tentang perbezaan "situasi" dalam data bahasa Melayu belum ditemui dalam kajian lampau. Oleh itu, kajian seterusnya dilakukan untuk mengenal pasti perkara yang belum diterangkan dalam kajian sebelum ini.

Sehubungan dengan kelompangan kajian literatur tersebut, kajian ini akan dijalankan dengan tujuan untuk menjelaskan strategi penolakan ajakan antara MNS dengan JNS dengan memperhatikan dua "situasi" ajakan yang berlainan.

Berdasarkan objektif kajian yang diutarakan tersebut, kajian ini membuat perbandingan antara MNS dengan JNS dari sudut kekerapan penggunaan formula semantik, iaitu klasifikasi ujaran mengikut kandungan semantik seperti yang disenaraikan dalam Jadual 1. Formula semantik ditulis dalam kurungan \{\} bagi artikel ini. Perbandingan antara dua kumpulan MNS dengan JNS turut dilakukan dalam kedua-dua konteks bahasa ibunda dan konteks antara budaya. Secara rumusannya, dua persoalan ditetapkan dalam artikel ini adalah seperti yang berikut.

Persoalan 1: Adakah strategi penolakan ajakan berbeza di antara MNS dengan JNS terhadap dua situasi yang berlainan dalam konteks bahasa ibunda? 
Persoalan 2: Adakah strategi penolakan ajakan berbeza di antara MNS dengan JNS terhadap dua situasi yang berlainan dalam konteks antara budaya?

\section{METODOLOGI}

\section{Kaedah Pengutipan Data}

Data wacana bagi kajian ini telah dikumpulkan mulai Mac hingga Mei 2019 di Malaysia. Kaedah pengutipan data yang diterapkan dalam kajian ini ialah lakonan terbuka menerusi aplikasi perkhidmatan rangkaian sosial (social networking service, selepas ini disebut sebagai SNS). Kad arahan disediakan sebagai elisitasi seperti Rajah 1 yang berikut. Kad arahan ditulis dalam dwibahasa, iaitu bahasa Jepun dan bahasa Melayu.

$$
\begin{aligned}
& \text { 1-A Bさんはあなたの友達です。 } \\
& \text { あなたは、今度の日曜日にBさんとショッピングに行きたいと思います。 } \\
& \text { Bさんにスマホでメッセージを送ってください。 } \\
& \text { B adalah } \underline{\text { rakan anda. }} \\
& \text { Anda ingin pergi membeli-belah bersama B pada hari Ahad depan. } \\
& \text { Anda hendaklah menghantar mesej kepada B dengan SNS. }
\end{aligned}
$$

1-B Aさんはあなたの友達です。

あなたは、Aさんにショッピングに誘われます。

しかし、その日は、ほかの予定が入っています。

Aさんからのメッセージに返信してください。

A adalah rakan anda.

Anda diajak untuk pergi membeli-belah bersama A.

Tetapi, anda mempunyai rancangan lain pada hari yang sama.

Anda hendaklah menjawab mesej daripada A.

Rajah 1 Set kad arahan. 
2-AＢさんはあなたの友達です。

あなたは、今度の日曜日のホームパーティーにBさんを誘おうと思います。

Bさんにスマホでメッセージを送ってください。

$B$ adalah rakan anda.

Anda ingin mengajak B untuk datang ke parti di rumah anda pada hari

Ahad depan.

Anda hendaklah menghantar mesej kepada B dengan SNS.

2-B Aさんはあなたの友達です。

あなたは、Aさんにホームパーティーに誘われます。

しかし、その日は、ほかの予定が入っています。

Aさんからのメッセージに返信してください。

A adalah rakan anda.

Anda diajak untuk datang ke parti di rumah A.

Tetapi, anda mempunyai rancangan lain pada hari yang sama.

Anda hendaklah menjawab mesej daripada A.

Samb. Rajah 1 Set kad arahan.

Kad arahan di atas menunjukkan dua situasi yang biasa ditemui dalam kehidupan seharian dalam masyarakat Melayu mahupun Jepun. Perbezaan antara dua situasi dalam kad arahan, (a) "membeli-belah" dan (b) "mengadakan parti", boleh dirumuskan seperti Jadual 1 dengan merujuk klasifikasi ajakan yang dibincangkan oleh Tsutsui (2002).

Situasi ajakan untuk (a) "membeli-belah" bertahap "kebiasaan" yang tinggi kerana perlakuan ini biasa dilakukan dalam kehidupan seharian dan boleh diulang banyak kali. Situasi (a) juga mempunyai tahap "kesegeraan" yang rendah kerana tindakan bersama tidak semestinya terus diambil selepas ajakan. Situasi (a) juga 
Jadual 1 Perbezaan antara dua situasi ajakan.

\begin{tabular}{cccc}
\hline Situasi Ajakan & Kebiasaan & Kesegeraan & $\begin{array}{c}\text { Keperluan } \\
\text { Perbincangan }\end{array}$ \\
\hline (a) Membeli-belah & Tinggi & Rendah & Tinggi \\
(b) Mengadakan parti & Rendah & Rendah & Rendah \\
\hline
\end{tabular}

merupakan tahap "keperluan perbincangan" yang tinggi kerana interlokutor perlu membincangkan masa dan tempat temu janji.

Situasi ajakan untuk (b) "mengadakan parti" pula bertahap "kebiasaan" yang rendah kerana parti biasanya dilakukan pada waktu yang tertentu dan istimewa sahaja. Situasi (b) juga mempunyai tahap "kesegeraan" yang rendah kerana perlakuan ini tidak semestinya terus dilakukan selepas ajakan, sama dengan situasi (a). Situasi (b) juga merupakan tahap "keperluan perbincangan" yang rendah kerana masa dan tempat selalunya ditetapkan terlebih dahulu oleh pengajak.

Informan bagi kajian ini seramai 20 orang MNS dan 20 orang JSN yang boleh dikawal oleh pengkaji dari segi kekangan masa dan tenaga. Kajian ini menyasarkan informan perempuan sahaja untuk mengelakkan pengaruh daripada faktor jantina. Usia informan juga ditetapkan dari 25 hingga 30 -an sahaja untuk meminimumkan pengaruh faktor usia. Informan MNS terdiri daripada golongan bekas pelajar antarabangsa di kolej atau universiti Jepun yang dihantar oleh kerajaan Malaysia untuk mengurangkan masalah pengetahuan leksikal dan tatabahasa dalam bahasa Jepun yang terhad. Selain itu, kajian ini memilih informan termasuk JNS yang tinggal di Malaysia sahaja sewaktu kajian ini dijalankan kerana informan boleh menetapkan kandungan ajakan dengan lebih realistik mengikut keadaan kawasan kediaman sendiri. Informan MNS ditandai dengan M01-M20, manakala informan JNS ditandai dengan J01-J20 dalam artikel ini. Pasangan dalam konteks antara budaya menunjukkan nombor yang sama seperti M01 dan J01.

Pasangan dalam konteks bahasa ibunda ditetapkan oleh pengkaji secara rawak dan diminta untuk berinteraksi seperti biasa dengan memainkan setiap peranan sebagai pengajak dan penolak bagi kedua-dua situasi. Kemudian, semua informan berpasangan dalam konteks antara budaya, dan diminta untuk memainkan setiap peranan sebagai pengajak dan penolak sekali lagi. Secara rumusannya, kajian ini menyasarkan sebanyak 160 data wacana seperti Jadual 2.

Bagi lakonan dalam konteks bahasa ibunda MNS, informan MNS menghantar mesej dalam bahasa Melayu menerusi aplikasi WhatsApp yang biasa digunakan dalam kalangan MNS. Bagi lakonan dalam konteks bahasa ibunda JNS serta 
Jadual 2 Jumlah data wacana yang disasarkan.

\begin{tabular}{lccc}
\hline \multicolumn{1}{c}{ Konteks } & $\begin{array}{c}\text { Jumlah } \\
\text { Kecil }\end{array}$ & Situasi & Jumlah \\
\hline Konteks bahasa ibunda & & & \\
$\quad$ Konteks MM (MNS=pengajak, MNS=penolak) & 20 & 2 & 40 \\
$\quad$ Konteks JJ (JNS=pengajak, JNS=penolak) & 20 & 2 & 40 \\
Konteks antara budaya & & & \\
$\quad$ Konteks MJ (MNS=pengajak, JNS=penolak) & 20 & 2 & 40 \\
Konteks JM (JNS=pengajak, MNS=penolak) & 20 & 2 & 40 \\
\hline
\end{tabular}

konteks antara budaya pula, informan menghantar mesej dalam bahasa Jepun dengan menggunakan aplikasi LINE yang paling popular di Jepun. Terdapat sedikit perbezaan antara dua aplikasi tersebut (Contoh: Lebih banyak koleksi pelekat (sticker) disediakan dalam aplikasi LINE), namun fungsi penghantaran mesej percuma yang ditulis dalam bentuk gelembung ucapan adalah tetap sama. Oleh yang demikian, data wacana yang dikutip menerusi dua aplikasi tersebut turut digunakan untuk menganalisis dalam kajian ini.

\section{Kaedah Penganalisisan Data}

Selepas data wacana dalam aplikasi SNS dikumpulkan, pengkaji membahagikan data tersebut kepada lima, iaitu "bahagian permulaan", "bahagian ajakan", "bahagian penolakan", "bahagian ajakan semula" serta "bahagian penutup" yang ditunjukkan oleh Nakagaki (2015).

Kemudian, pengkaji menandakan formula semantik bagi setiap ujaran penolak yang ditemui dalam "bahagian ajakan", "bahagian penolakan" dan "bahagian ajakan semula". Ujaran seperti "Ahad ka... jap check kalendar" (\{ulangan $\}+\{$ aksi pengesahan $\}$ ) juga merupakan sebahagian strategi penolakan dengan memberi ruang masa sebelum niat penolakan dikemukakan walaupun ujaran tersebut menjadi respons dalam "bahagian ajakan".

Jadual 3 ialah senarai formula semantik terhadap penolakan ajakan bagi kajian ini. Kajian ini merujuk senarai formula semantik yang dipaparkan oleh Ikoma dan Shimura (1993), Ito (2002) serta Mekkreangkrai (2013), dan telah mengubah suai dan menambah formula semantik mengikut keperluan dalam data kajian ini. Contoh dalam Jadual 3 menunjukkan ekspresi yang telah diringkaskan oleh 
Jadual 3 Senarai formula semantik terhadap strategi penolakan ajakan.

\begin{tabular}{|c|c|c|c|}
\hline & Formula Semantik & Fungsi Semantik & Contoh \\
\hline 1 & \{panggilan\} & Menyebut kata panggilan & XXX/Awak/Beb \\
\hline 2 & $\{$ pertanyaan tujuan\} & Memastikan tujuan utama & Kenapa?/Ada apa? \\
\hline 3 & $\{$ ulangan $\}$ & Mengulang ujaran & Ahad depan ye \\
\hline 4 & \{permohonan kepastian\} & Memohon kepastian & Ahad ni ke ahad depan? \\
\hline 5 & $\{$ pemberian kepastian\} & Memberi kepastian & Haah \\
\hline 6 & $\{$ aksi pengesahan $\}$ & Mengesahkan kelapangan & Jap nak check jadual \\
\hline 7 & $\{$ kata seru negatif $\}$ & Meluahkan seruan negatif & Alaa.../Alamak/Mmm... \\
\hline 8 & $\{$ kata seru positif $\}$ & Meluahkan seruan positif & Wow/Wah \\
\hline 9 & $\{$ permohonan maaf & Memohon maaf & Maaf/Sorry \\
\hline 10 & $\{$ sebab konkrit\} & Menyatakan sebab konkrit & Saya nak balik kampung \\
\hline 11 & $\{$ sebab kabur $\}$ & Menyatakan sebab kabur & Saya ada hal \\
\hline 12 & $\{$ sebab tambahan $\}$ & Menambah sebab & Ada kenduri \\
\hline 13 & $\{$ keputusan $\}$ & Menyatakan keputusan & Tak boleh/Susah \\
\hline 14 & $\{$ penangguhan $\}$ & Menyatakan penangguhan & Kalau sempat saya datang \\
\hline 15 & $\{$ penghargaan\} & Menyatakan penghargaan & Terima kasih \\
\hline 16 & $\{$ khuatir\} & Menunjukkan kekhuatiran & Walhal sudah diajak \\
\hline 17 & $\{$ reaksi positif $\}$ & Memberi reaksi positif & Nak pergi/Mesti seronok \\
\hline 18 & $\{$ kesedihan\} & Menunjukkan kesedihan & Saya sedih/Saya kecewa \\
\hline 19 & \{permintaan maklumat\} & Meminta maklumat & Untuk apa?/Pukul berapa? \\
\hline 20 & $\{$ kefahaman $\}$ & Menunjukkan kefahaman & Ye ke/Oh begitu \\
\hline 21 & $\{$ empati\} & Menunjukkan empati & Kan.../Saya pun/Tu la... \\
\hline 22 & $\{$ keterujaan $\}$ & Menunjukkan keterujaan & Ini betul-betul menggugat \\
\hline 23 & $\{$ ketawa $\}$ & Menunjukkan ketawa & Hahaha/Hehe/Huhu \\
\hline 24 & $\{$ ucapan $\}$ & Menyatakan ucapan & Selamat hari jadi! \\
\hline 25 & $\{$ gantian\} & Menyatakan gantian & $\begin{array}{l}\text { Saya bagi hadiah } \\
\text { kemudian }\end{array}$ \\
\hline 26 & $\{$ cadangan $\}$ & Mencadangkan masa lain & Ahad lagi satu ok tak? \\
\hline 27 & $\{$ pengekalan hubungan\} & Mengekalkan hubungan & Lain kali kita jumpa \\
\hline 28 & $\{$ lain-lain $\}$ & Tidak dinyatakan di atas & Timing tak kena/x pe la \\
\hline
\end{tabular}

pengkaji. Ekspresi dalam bahasa Jepun telah diterjemahkan ke bahasa Melayu dan ditulis dengan huruf yang dicondongkan. Kata nama khas digantikan dengan "XXX" dalam artikel ini.

Penandaan formula semantik bagi semua data dijalankan oleh pengkaji secara berasingan. Kemudian, penandaan formula semantik kali kedua dilakukan oleh seorang penutur asli bagi setiap bahasa. Seterusnya, analisis Cohen's Kappa diterapkan untuk mengenal pasti tahap kebolehpercayaan antara dua orang penanda. 
Penandaan formula semantik bagi data bahasa Melayu dapat diperoleh $\kappa=.887$ $(>.70)$, dan $\kappa=.903(>.70)$ bagi data bahasa Jepun dengan menggunakan Cohen's Kappa. Penandaan formula semantik boleh dianggap sebagai tugas subjektif dan angka yang lebih daripada 0.7 bermaksud boleh dipercayai (Hotta, 2017). Sekiranya dua orang penanda membuat penandaan yang berlainan, pengkaji memutuskan penandaan akhir atas perbincangan di antara mereka.

Yang berikut ialah contoh penandaan formula semantik bagi informan M10 dan J18. Informan M10 menggunakan \{kata seru negatif\}, \{ulangan\}, \{sebab kabur\}, \{pemberian kepastian\} dan \{sebab tambahan\}, manakala informan J18 menggunakan \{ulangan\}, \{permohonan maaf\}, \{sebab kabur\}, \{reaksi positif\} dan $\{$ keputusan $\}$.

M09: XXX, ahad depan, jom shopping?

M10: alaa \{kata seru negatif\}, ahad depan ke \{ulangan\} saya dah ada plan lain la \{sebab kabur\}

M09: Alaaa x free pulak

M10: haah \{pemberian kepastian\}, dah janji dgn family \{sebab tambahan\}

M09: Ok takpe. Nanti kita set hari lain.

J15：今週の日曜日予定あるかな？ランチとショッピングどうかな？

Hari Ahad minggu ni ada pelan tak? Kalau lunch dengan shopping macam mana?

J18：今週の、日曜かごめん、私予定はいっててさい、、 めっちゃ行きたいんだけど、、行けない

Ahad minggu ni ya \{ulangan\}. Maaf \{permohonan maaf\}, saya dah ada pelan pula.. \{sebab kabur\} Saya nak sangat pergi.. \{reaksi positif\} tapi tak dapat \{keputusan\}.

J15: そうなんだね残念!

Begitu ya. Sayangnya!

Formula semantik yang digunakan oleh kurang daripada 10\% informan bagi semua kategori dikumpulkan sebagai \{lain-lain\} dalam artikel ini. Kajian ini tidak mengambil kira informasi visual seperti emotikon (Contoh: $\left({ }^{\wedge}{ }_{-}^{\wedge}\right)$ dan $\left(>_{-}<\right)$), emoji (Contoh: dan) dan pelekat (sticker) sebagai formula semantik. 
Setelah formula semantik ditandakan bagi setiap ujaran, kekerapannya dihitung mengikut kumpulan MNS dan JNS secara berasingan. Jumlah perbezaan (bukan jumlah keseluruhan) dikira dalam kajian ini untuk mementingkan "apa yang perlu dinyatakan”. Dengan kata lain, berapa ramai informan dalam kedua-dua kumpulan MNS dan JNS menggunakan setiap jenis formula semantik dihitung dalam kajian ini.

Seterusnya, Ujian Fisher (Fisher's exact test) dijalankan untuk mengenal pasti sama ada wujud atau tidak perbezaan signifikan antara dua kumpulan yang dibandingkan dari segi kekerapan penggunaan formula semantik. Aras signifikan dua hujung yang digunakan dalam artikel ini ialah 0.05 . Sekiranya nilai signifikan $(p)$ mendapati angka yang lebih besar daripada 0.05 , bermaksud perbezaan signifikan antara dua kumpulan yang dibandingkan tidak wujud. Perbandingan antara dua kumpulan MNS dengan JNS turut dilakukan bagi kedua-dua "situasi" yang ditetapkan dalam konteks bahasa ibunda mahupun konteks antara budaya.

Sekiranya strategi penolakan oleh MNS dalam konteks antara budaya serupa dengan MNS dalam konteks bahasa ibunda, tetapi berbeza dengan JNS, strategi penolakan ini dianggap sebagai "pemindahan pragmatik", iaitu pengaruh daripada bahasa ibunda kepada bahasa sasaran. Sedangkan, apabila strategi penolakan oleh MNS dalam konteks antara budaya serupa dengan JNS, tetapi berbeza dengan MNS dalam konteks bahasa ibunda, strategi penolakan ini dianggap sebagai "akomodasi", iaitu penyesuaian diri dengan norma dalam bahasa sasaran.

\section{HASIL KAJIAN DAN PERBINCANGAN}

\section{Perbandingan Kekerapan Penggunaan Formula Semantik dalam Konteks Bahasa Ibunda}

Jadual 4 merupakan hasil perbandingan dari segi kekerapan penggunaan formula semantik antara MNS dengan JNS dalam konteks bahasa ibunda.

Bagi situasi (a) "membeli-belah", tujuh jenis formula semantik menunjukkan perbezaan signifikan $(\mathrm{p}<.05)$ antara MNS dengan JNS. Antaranya termasuklah lima jenis formula semantik lebih kerap digunakan oleh MNS berbanding dengan JNS, iaitu \{kata seru negatif\}, \{sebab konkrit\}, \{sebab tambahan\}, \{permintaan maklumat\} dan \{ketawa\}. Sebanyak dua jenis formula semantik, iaitu \{sebab kabur\} dan \{penghargaan\} pula lebih kerap digunakan oleh JNS berbanding dengan MNS.

Bagi situasi (b) "mengadakan parti" pula, sembilan jenis formula semantik menunjukkan perbezaan signifikan antara MNS dengan JNS. Sebanyak enam jenis 
Jadual 4 Perbandingan kekerapan penggunaan formula semantik dalam konteks bahasa ibunda.

\begin{tabular}{|c|c|c|c|c|c|c|c|}
\hline & \multirow[b]{2}{*}{$\begin{array}{c}\text { Formula } \\
\text { Semantik }\end{array}$} & \multicolumn{3}{|c|}{ Situasi (a): Membeli-belah } & \multicolumn{3}{|c|}{ Situasi (b): Mengadakan Parti } \\
\hline & & $\begin{array}{l}\text { MNS } \\
(n=20\end{array}$ & $\begin{array}{c}\text { JNS } \\
(n=20)\end{array}$ & Nilai-p & $\begin{array}{l}\text { MNS } \\
(n=20)\end{array}$ & $\begin{array}{c}\text { JNS } \\
(n=20)\end{array}$ & Nilai- \\
\hline 1 & \{panggilan & 9 & 3 & 0.082 & 9 & 2 & $0.031^{*}$ \\
\hline 2 & $\begin{array}{l}\text { \{pertanyaan } \\
\text { tujuan\} }\end{array}$ & 4 & 1 & 0.342 & 3 & 1 & 0.605 \\
\hline 3 & $\{$ ulangan & 7 & 3 & 0.273 & 9 & 7 & 0.748 \\
\hline 4 & $\begin{array}{l}\text { \{permohonan } \\
\text { kepastian\} }\end{array}$ & 5 & 1 & 0.182 & 2 & 2 & 1.000 \\
\hline 5 & $\begin{array}{l}\text { \{pemberian } \\
\text { kepastian }\end{array}$ & 3 & 0 & 0.231 & 1 & 0 & 1.000 \\
\hline 6 & \{aksi pengesahan\} & 5 & 1 & 0.182 & 2 & 0 & 0.487 \\
\hline 7 & $\begin{array}{l}\{\text { kata seru } \\
\text { negatif\} }\end{array}$ & 12 & 1 & $0.000 * *$ & 13 & 0 & $0.000^{* *}$ \\
\hline 8 & $\{$ kata seru positif\} & 1 & 1 & 1.000 & 8 & 0 & $0.003 * *$ \\
\hline 9 & $\begin{array}{l}\{\text { permohonan } \\
\text { maaf\} }\end{array}$ & 8 & 13 & 0.205 & 12 & 9 & 0.527 \\
\hline 10 & $\{$ sebab konkrit\} & 13 & 4 & $0.010^{* *}$ & 16 & 7 & $0.010^{* *}$ \\
\hline 11 & $\{$ sebab kabur $\}$ & 7 & 16 & $0.010 * *$ & 4 & 11 & $0.048^{*}$ \\
\hline 12 & $\{$ sebab tambahan $\}$ & 7 & 0 & $0.008 * *$ & 14 & 4 & $0.004 * *$ \\
\hline 13 & $\{$ keputusan\} & 8 & 7 & 1.000 & 9 & 9 & 1.000 \\
\hline 14 & $\{$ penangguhan & 0 & 0 & 1.000 & 4 & 1 & 0.342 \\
\hline 15 & $\{$ penghargaan & 0 & 7 & $0.008 * *$ & 4 & 4 & 1.000 \\
\hline 16 & $\{$ khuatir\} & 0 & 1 & 1.000 & 0 & 3 & 0.231 \\
\hline 17 & $\{$ reaksi positif\} & 2 & 7 & 0.127 & 5 & 18 & $0.000 * *$ \\
\hline 18 & $\{$ kesedihan $\}$ & 0 & 0 & 1.000 & 1 & 7 & $0.044 *$ \\
\hline 19 & $\begin{array}{l}\text { \{permintaan } \\
\text { maklumat\} }\end{array}$ & 8 & 1 & $0.020^{*}$ & 12 & 3 & $0.008 * *$ \\
\hline 20 & $\{$ kefahaman $\}$ & 2 & 0 & 0.487 & 7 & 3 & 0.273 \\
\hline 21 & $\{$ empati\} & 2 & 0 & 0.487 & 4 & 0 & 0.106 \\
\hline 22 & $\{$ keterujaan\} & 2 & 0 & 0.487 & 6 & 1 & 0.092 \\
\hline 23 & $\{$ ketawa $\}$ & 9 & 2 & $0.031 *$ & 8 & 2 & 0.065 \\
\hline 24 & $\{$ ucapan $\}$ & 0 & 0 & 1.000 & 1 & 0 & 1.000 \\
\hline 25 & $\{$ gantian\} & 0 & 0 & 1.000 & 2 & 0 & 0.487 \\
\hline 26 & \{cadangan\} & 10 & 13 & 0.523 & 0 & 1 & 1.000 \\
\hline 27 & $\begin{array}{l}\text { \{pengekalan } \\
\text { hubungan\} }\end{array}$ & 2 & 3 & 1.000 & 3 & 4 & 1.000 \\
\hline 28 & $\{$ lain-lain & 7 & 2 & 0.127 & 4 & 3 & 1.000 \\
\hline
\end{tabular}


formula semantik lebih kerap digunakan oleh MNS berbanding dengan JNS secara signifikan, iaitu \{panggilan\}, \{kata seru negatif\}, \{kata seru positif\}, \{sebab konkrit\}, \{sebab tambahan\} dan \{permintaan maklumat\}. Sementara itu, sebanyak tiga jenis formula semantik \{sebab kabur\}, \{reaksi positif\} dan \{kesedihan\} lebih kerap digunakan oleh JNS berbanding dengan MNS.

Kajian ini mendapati bahawa lebih daripada 90\% bagi kedua-dua kumpulan MNS dan JNS menyatakan sesuatu \{sebab\} bagi setiap situasi ajakan dalam konteks bahasa ibunda. Dengan ini, jelasnya formula semantik \{sebab \} memainkan peranan yang paling penting untuk menyampaikan "niat penolakan" dalam bahasa Melayu mahupun bahasa Jepun. Hal ini merupakan satu persamaan yang ketara antara MNS dengan JNS.

Walaupun begitu, boleh dirumuskan bahawa informan MNS lebih mementingkan "kesantunan positif", manakala informan JNS lebih menitikberatkan "kesantunan negatif" (Hieda et al., 2021). "Kesantunan positif" merupakan tindakan untuk menjaga keinginan ke arah yang positif, seperti ingin disukai, ingin difahami, ingin dipuji serta ingin dijadikan ahli kumpulan yang lain, manakala "kesantunan negatif" merujuk tindakan yang menjaga keinginan ke arah yang negatif, seperti tidak ingin dikekang, tidak ingin diganggu dan sebagainya (Usami, 2003).

Secara lebih konkrit, informan MNS lebih kerap menggunakan formula semantik \{sebab konkrit\}, \{sebab tambahan\} dan \{permintaan maklumat\} secara signifikan dalam konteks bahasa ibunda untuk berkongsi informasi peribadi yang lebih teliti antara interlokutor. Tiga jenis formula semantik tersebut berkesan untuk mendekatkan diri dengan lawan tutur secara psikologi. Informan JNS pula lebih cenderung untuk memberikan maklumat peribadi yang minimum sahaja dengan menjauhkan diri daripada lawan tutur untuk melindungi keperibadian.

Kecenderungan yang berlainan terhadap pemilihan strategi kesantunan positif atau negatif tersebut menunjukkan bahawa rakan setaraf dalam bahasa Melayu lebih dianggap sebagai entiti " $u c h i$ " (dalam kumpulan, terdiri daripada penutur sendiri dan ahli keluarga), manakala rakan setaraf dalam bahasa Jepun lebih dianggap sebagai entiti "soto" (luar kumpulan). Menurut Miyake (1994), "kesopanan" dalam bahasa Jepun direalisasikan dengan membezakan entiti "uchi" (dalam kumpulan) dan entiti "soto" (luar kumpulan) secara jelas. Sebaliknya, "kesopanan" dalam bahasa Melayu lebih direalisasikan dengan melayan entiti "soto" (luar kumpulan) sebagai "uchi" (dalam kumpulan) dengan mesra, seolah-olah rakan setaraf ialah seorang ahli keluarga.

Apabila dua situasi dalam Jadual 3 dibandingkan, lima jenis formula semantik, iaitu \{kata seru negatif\}, \{sebab konkrit\}, \{sebab tambahan\} dan \{permintaan maklumat\} yang kerap digunakan oleh MNS serta \{sebab kabur\} yang kerap digunakan oleh JNS 
tetap menunjukkan perbezaan signifikan bagi kedua-dua situasi yang dibandingkan. Lima jenis formula semantik tersebut menjadi elemen utama yang menggambarkan perbezaan antara MNS dengan JNS tanpa mengambil kira perbezaan "situasi" ajakan.

Sebaliknya empat jenis formula semantik yang lain, iaitu \{panggilan\}, \{kata seru positif\}, \{reaksi positif\} dan \{kesedihan\} merupakan perbezaan signifikan yang hanya ditemui dalam situasi (b) "mengadakan parti". Bagi dua jenis formula semantik \{penghargaan\} dan \{ketawa\} pula, perbezaan signifikan dalam situasi (a) "membeli-belah" tidak lagi wujud dalam situasi (b) "mengadakan parti". Hal ini jelasnya menunjukkan bahawa perbezaan signifikan bukan sahaja dipengaruhi oleh perbezaan bahasa, malah juga dipengaruhi oleh perbezaan "situasi" ajakan.

Penggunaan formula semantik teras dalam wacana penolakan ajakan seperti \{sebab\}, \{keputusan\} dan \{permohonan maaf\} tidak menunjukkan perbezaan ketara antara situasi (a) "membeli-belah" dengan situasi (b) "mengadakan parti". Dalam erti kata lain, cara penyampaian "niat penolakan" kurang terdedah kepada perbezaan "situasi".

Sebaliknya, boleh dikatakan bahawa penggunaan formula semantik yang berkait rapat dengan cara penyampaian "minat" lebih mudah dipengaruhi oleh perbezaan "situasi". Kedua-dua kumpulan MNS dan JNS kerap menunjukkan \{cadangan\} bagi situasi (a) "membeli-belah" kerana situasi tersebut bertahap "kebiasaan” yang tinggi, iaitu ajakan boleh dilaksanakan pada hari yang lain. Kedua-dua kumpulan MNS dan JNS juga secara tidak langsung dapat menunjukkan "minat" terhadap kandungan ajakan serta hasrat untuk memenuhi kehendak pengajak dengan menggunakan \{cadangan\}. Namun demikian, \{cadangan\} tidak sesuai bagi situasi (b) "mengadakan parti" kerana situasi tersebut bertahap "keperluan perbincangan" yang rendah, iaitu tarikh ajakan sukar ditukar kepada hari yang lain. Pengajak juga sukar membuat lagi parti yang sama pada hari yang lain disebabkan oleh tahap "kebiasaan" yang rendah.

Sehubungan itu, bagi situasi (b) "mengadakan parti", informan MNS lebih kerap menggunakan \{kata seru positif\} seperti "wah" untuk menunjukkan "minat" secara tidak langsung, manakala JNS lebih kerap menggunakan \{reaksi positif\} seperti "ikitai" (nak pergi) untuk menunjukkan "minat" secara lebih eksplisit. Informan JNS juga lebih kerap menekankan emosi sedih secara langsung dengan menyatakan \{kesedihan\} seperti "zannen" (sedih/kecewa) atau "sugoku zannen" (sangat sedih).

Perbezaan antara dua kumpulan MNS dengan JNS terhadap penyampaian "minat" tersebut boleh diterangkan melalui faktor "manfaat" yang telah ditunjukkan oleh Kawaguchi et al. (2002). Hieda (2019) turut membincangkan bahawa pengajak MNS melakukan "ajakan" dengan lebih menekankan "manfaat" bagi "lawan tutur", iaitu "untuk memberikan peluang yang baik kepada lawan tutur", manakala pengajak JNS lebih menekankan "manfaat" bagi "diri sendiri", iaitu "untuk merapatkan persahabatan antara interlokutor". 
Kecenderungan MNS yang kerap menunjukkan "minat" secara tidak langsung boleh dikaitkan dengan penjagaan perasaan sendiri yang tidak dapat menerima "manfaat" parti yang disediakan oleh pengajak. Semakin berminat penolak MNS untuk sertai parti, semakin kecewa beliau apabila ajakan tidak dapat direalisasikan. Sekiranya penolak MNS berasa kecewa, maka pengajak MNS juga berasa kecewa. Hal ini bertentangan dengan hasrat ajakan asal yang ingin berkongsi kegembiraan. Oleh yang demikian, penolak MNS menunjukkan "minat" secara tidak langsung dengan mengelakkan terjadinya kekecewaan antara kedua-dua pihak pengajak dan penolak.

Sementara itu, informan JNS lebih menitikberatkan perkongsian kedua-dua perasaan gembira dan sedih dengan menekankan "manfaat" yang didapati daripada ajakan itu sendiri, iaitu untuk mengeratkan hubungan antara interlokutor. Penekanan "manfaat" bagi "diri sendiri" juga secara tidak langsung mengurangkan "beban" bagi "lawan tutur" (Hieda, 2019). Semakin mendalam perkongsian emosi gembira dan sedih, semakin baik hubungan antara interlokutor bagi informan JNS tanpa mengambil kira keputusan sebagai penolakan. Penolak JNS juga tetap bergembira dan bersyukur kerana pengajak telah memilih beliau untuk melakukan sesuatu bersama-sama.

Sebagai tambahan, \{reaksi positif\} yang kerap digunakan oleh JNS lebih berkesan untuk mengelakkan salah faham seolah-olah ajakan tidak diingini atau tidak diminati apabila digunakan secara bersama \{sebab kabur\}. Hon (2007) dan Laohaburanakit (1995) membincangkan bahawa sekiranya penolakan dilakukan atas faktor masa atau kemampuan, pengajak boleh memahami keadaan secara sepenuhnya dengan alasan yang jujur. Namun begitu, JNS lebih cenderung untuk memberikan \{sebab kabur\} walaupun penolakan dilakukan atas faktor masa atau kemampuan. Hal ini kerana JNS mengelakkan situasi yang perlu menyatakan alasan yang sukar untuk dinyatakan atau alasan yang tidak ingin dinyatakan dengan menjadikan \{sebab kabur\} sebagai alasan yang biasa digunakan.

Secara lebih konkrit, terdapat informan MNS yang menyatakan \{sebab konkrit\} secara jujur, iaitu pelan untuk membawa adik ke hospital disebabkan oleh pembedahan yang dilakukan pada minggu lepas. Namun demikian, tiada JNS yang menyatakan \{sebab konkrit\} yang agak sensitif seperti ini, sebaliknya semua JNS memberikan \{sebab konkrit\} positif yang boleh menyeronokkan penutur seperti "berjumpa ibu bapa" dan "pergi jalan-jalan bersama keluarga". Dalam erti kata lain, MNS lebih cenderung untuk berkongsi informasi kegembiraan mahupun kesusahan antara interlokutor melalui pelbagai jenis \{sebab konkrit\} yang biasa digunakan dalam masyarakat Melayu. 


\section{Perbandingan Kekerapan Penggunaan Formula Semantik dalam Konteks antara Budaya}

Jadual 5 ialah hasil perbandingan dari segi kekerapan penggunaan formula semantik antara MNS dengan JNS dalam konteks antara budaya.

Bagi konteks antara budaya, perbezaan signifikan antara MNS dengan JNS tidak ditemui bagi situasi (a) "membeli-belah" dan hanya dua jenis formula semantik sampingan menunjukkan berbezaan signifikan bagi situasi (b) "mengadakan parti". Perbezaan signifikan yang ditemui dalam konteks bahasa ibunda sudah tidak wujud dalam konteks antara bahasa.

Hal ini menunjukkan bahawa kedua-dua kumpulan MNS dan JNS lebih cenderung untuk memilih norma bahasa Jepun yang dituturkan walaupun mereka tinggal di Malaysia sewaktu kajian ini dijalankan. Pendekatan MNS telah berubah untuk lebih menitikberatkan "kesantunan negatif" dalam konteks antara budaya, manakala informan JNS kekal sahaja dengan menekankan strategi "kesantunan negatif".

Secara lebih konkrit, kekerapan bagi formula semantik \{sebab konkrit\}, \{sebab tambahan\} dan \{permintaan maklumat\} yang digunakan oleh MNS telah berkurang, manakala kekerapan bagi \{sebab kabur\} dan \{reaksi positif\} oleh MNS telah meningkat dalam konteks antara budaya mengikut cara penolakan JNS. Dalam erti kata lain, informan MNS telah mengubah cara penyampaian "niat penolakan" dengan kerap memberikan \{sebab kabur\} apabila mereka berinteraksi dengan JNS. Informan MNS juga telah berubah untuk menunjukkan "minat" secara lebih eksplisit dengan kerap memberikan \{reaksi positif\} bagi situasi (b) "mengadakan parti" dalam konteks antara budaya. Perubahan strategi tersebut menunjukkan "akomodasi" yang menyesuaikan diri dengan norma bahasa sasaran. Sikap "akomodasi" tersebut melambangkan nilai Melayu yang cuba untuk mengelakkan konflik antara budaya yang berlainan (Awang et al., 2012; Paramasivam, 2007).

Dua jenis formula semantik yang menunjukkan perbezaan signifikan bagi situasi (b) "mengadakan parti" berkait rapat dengan imej "parti di rumah" yang berlainan antara MNS dengan JNS. Informan MNS lebih cenderung untuk menyambut sesuatu secara berkumpulan dalam bentuk parti di rumah, manakala JNS lebih berorientasi untuk bersantai di rumah bersama-sama dengan rakan yang rapat (Hieda et al., 2021).

Oleh yang demikian, informan JNS kerap menggunakan \{ucapan\} dan \{gantian\} dalam konteks antara budaya terhadap parti hari jadi atau parti untuk berpindah ke rumah baharu yang diajak oleh MNS.

Penggunaan formula semantik \{ucapan\} menunjukkan perbezaan antara MNS dengan JNS. Informan JNS kerap memberikan \{ucapan\} seperti "Otanjoobi omedetoo" (Selamat hari jadi) kepada ahli keluarga MNS yang akan disambut pada parti hari jadi, 
Jadual 5 Perbandingan kekerapan penggunaan formula semantik dalam konteks antara budaya.

\begin{tabular}{|c|c|c|c|c|c|c|c|}
\hline & \multirow[b]{2}{*}{$\begin{array}{l}\text { Formula } \\
\text { Semantik }\end{array}$} & \multicolumn{3}{|c|}{ Situasi (a): Membeli-belah } & \multicolumn{3}{|c|}{ Situasi (b): Mengadakan Parti } \\
\hline & & $\begin{array}{l}\text { MNS } \\
(n=20\end{array}$ & $\begin{array}{c}\text { JNS } \\
(n=20)\end{array}$ & Nilai-p & $\begin{array}{l}\text { MNS } \\
(n=20\end{array}$ & $\begin{array}{c}\mathrm{JNS} \\
(n=20)\end{array}$ & Nilai- \\
\hline 1 & \{panggilan\} & 2 & 2 & 1.000 & 1 & 1 & 1.000 \\
\hline 2 & $\begin{array}{l}\text { \{pertanyaan } \\
\text { tujuan\} }\end{array}$ & 1 & 5 & 0.182 & 2 & 4 & 0.422 \\
\hline 3 & $\{$ ulangan\} & 11 & 6 & 0.200 & 7 & 9 & 0.748 \\
\hline 4 & \{permohonan & 1 & 1 & 1.000 & 0 & 0 & 1.000 \\
\hline 5 & kepastian\} & 1 & 2 & 1.000 & 2 & 0 & 0.487 \\
\hline 6 & $\{$ aksi pengesahan\} & 4 & 1 & 0.342 & 0 & 0 & 1.000 \\
\hline 7 & $\{$ kata seru negatif\} & 7 & 4 & 0.480 & 4 & 3 & 1.000 \\
\hline 8 & $\{$ kata seru positif\} & 1 & 1 & 1.000 & 6 & 4 & 0.716 \\
\hline 9 & $\begin{array}{l}\text { \{permohonan } \\
\text { maaf\} }\end{array}$ & 15 & 12 & 0.501 & 11 & 12 & 1.000 \\
\hline 10 & $\{$ sebab konkrit\} & 7 & 5 & 0.731 & 11 & 8 & 0.527 \\
\hline 11 & $\{$ sebab kabur\} & 12 & 13 & 1.000 & 7 & 11 & 0.341 \\
\hline 12 & $\{$ sebab tambahan\} & 0 & 1 & 1.000 & 5 & 2 & 0.408 \\
\hline 13 & $\{$ keputusan\} & 9 & 7 & 0.748 & 7 & 8 & 1.000 \\
\hline 14 & \{penangguhan\} & 1 & 0 & 1.000 & 1 & 2 & 1.000 \\
\hline 15 & $\{$ penghargaan\} & 0 & 3 & 0.231 & 1 & 3 & 0.605 \\
\hline 16 & $\{$ khuatir\} & 0 & 1 & 1.000 & 1 & 3 & 0.605 \\
\hline 17 & $\{$ reaksi positif\} & 10 & 13 & 0.523 & 16 & 15 & 1.000 \\
\hline 18 & $\{$ kesedihan\} & 1 & 0 & 1.000 & 4 & 6 & 0.716 \\
\hline 19 & $\begin{array}{l}\text { \{permintaan } \\
\text { maklumat\} }\end{array}$ & 4 & 1 & 0.342 & 3 & 5 & 0.695 \\
\hline 20 & $\{$ kefahaman & 1 & 3 & 0.605 & 1 & 4 & 0.342 \\
\hline 21 & $\{$ empati\} & 0 & 1 & 1.000 & 1 & 2 & 1.000 \\
\hline 22 & $\{$ keterujaan\} & 0 & 0 & 1.000 & 0 & 1 & 1.000 \\
\hline 23 & $\{$ ketawa $\}$ & 1 & 1 & 1.000 & 0 & 1 & 1.000 \\
\hline 24 & $\{$ ucapan\} & 0 & 0 & 1.000 & 1 & 8 & $0.020^{*}$ \\
\hline 25 & \{gantian\} & 0 & 0 & 1.000 & 0 & 7 & $0.008^{* *}$ \\
\hline 26 & \{cadangan\} & 6 & 11 & 0.200 & 0 & 0 & 1.000 \\
\hline 27 & $\begin{array}{l}\text { \{pengekalan } \\
\text { hubungan\} }\end{array}$ & 1 & 2 & 1.000 & 2 & 2 & 1.000 \\
\hline 28 & $\{$ lain-lain $\}$ & 2 & 2 & 1.000 & 1 & 2 & 1.000 \\
\hline
\end{tabular}

$* \mathrm{p}<.05, * * \mathrm{p}<.01$ 
manakala informan MNS langsung tidak mengucapkan "Selamat hari jadi” terhadap hari jadi ahli keluarga lawan tutur. Hal ini berkaitan dengan konsep "uchi" (dalam kumpulan), iaitu JNS lebih cenderung menganggap perkara yang berlaku pada ahli keluarga seolah-olah terjadi pada diri sendiri (Miyake, 1994).

Penggunaan \{gantian\} juga berbeza antara MNS dengan JNS apabila dipengaruhi oleh struktur wacana yang berlainan. Formula semantik \{gantian\} juga kerap digunakan oleh MNS, tetapi 30\% (6 orang) MSN menggunakannya dalam bahagian penutup selepas penolakan diterima oleh pengajak. Sementara itu, informan JNS kerap menggunakan \{gantian\} sebelum penolakan diterima oleh pengajak. Misalnya, terdapat ujaran seperti "Paathi ni wa sanka dekinai kedo, kondo atta toki ni oiwai suru ne" (Tak dapat nak datang parti, tapi kalau jumpa lain kali saya sambut pula ya) yang menjadikan pengajak untuk menerima penolakan dengan lebih senang hati.

\section{KESIMPULAN}

Kajian ini menjalankan kajian sosiopragmatik untuk menjelaskan strategi penolakan ajakan yang digunakan oleh MNS dan JNS dengan memperhatikan perbezaan "situasi". Kajian ini mendapati bahawa formula semantik yang menyampaikan "niat penolakan" kurang terdedah pada perbezaan situasi, sebaliknya cara penyampaian "minat" lebih dipengaruhi oleh perbezaan situasi. Selain itu, perbezaan signifikan yang ditemui dalam konteks bahasa ibunda tidak lagi wujud dalam konteks antara budaya. Secara rumusannya, kajian ini menunjukkan bahawa MNS secara proaktif memilih norma dalam bahasa sasaran untuk menjayakan komunikasi antara budaya yang lancar. Kajian ini telah menonjolkan pengaruh "situasi" terhadap strategi penolakan serta daya keterbukaan dalam kalangan MNS yang mengelakkan konflik. Walau bagaimanapun, kajian ini hanya menyasarkan 20 orang informan bagi setiap MNS dan JNS. Jika kajian dapat dilaksanakan dengan lebih ramai informan, dapatan kajian ini boleh dikukuhkan. Sebagai cadangan untuk masa hadapan, kajian seterusnya boleh menjelaskan sempadan "akomodasi", iaitu strategi yang boleh diikuti oleh MNS dan strategi yang sukar diikuti oleh MNS dalam budaya yang berlainan. 
PENOLAKAN AJAKAN DALAM MASYARAKAT MELAYU DAN JEPUN: SATU KAJIAN SOSIOPRAGMATIK

\section{RUJUKAN}

Awang, S., Maros, M., \& Ibrahim, N. (2012). Malay values in intercultural communication. International Journal of Social Science and Humanity, 2(3), 201-205.

Embassy of Japan in Malaysia. (2021, April 5). The Malaysian Look East Policy. Retrieved from https://www.my.emb-japan.go.jp/English/JIS/education/LEP.htm

Fujimori, H. (1995). The forms of explanation markers and their pragmatic functions: In the case of Chinese and Korean students of Japanese. Journal of Japanese Language Teaching, 87, 79-90.

Hieda, N. (2019). Nihongo kyoukasho no kanyuu bamen ni okeru mareego bogowasha no gengo koudou: Nihongo bogowasha ga mainasu hyouka o kudasu koumoku o chuushin ni (Perlakuan linguistik oleh penutur asli bahasa Melayu terhadap situasi ajakan dalam buku teks bahasa Jepun: Fokus kepada perlakuan yang dinilai negatif oleh penutur asli bahasa Jepun). Kaigai Nihongo Kyouiku Kenkyuu, 8, 1-15.

Hieda, N., Nor Hashimah Jalaluddin, \& Mohammad Fadzeli Jaafar. (2021). Penolakan ajakan dalam bahasa Jepun oleh informan Melayu: Analisis strategi dan kesan kesantunan. GEMA Online ${ }^{\circledR}$ Journal of Language Studies, 21(1), 148-165.

Hon, M. (2007). Nikkan ryoukokunin no gengo koudou no chigai: Kotowari no sutoratejii no nikkan hikaku (Perbezaan lakuan bahasa di antara orang Jepun dengan orang Korea: Perbandingan strategi penolakan). Nihongogaku, 26(1), 80-90.

Hotta, T. (2017). Disagreement acts by Chinese learners of Japanese: The possibility of pragmatic transfer in strategy usage. Journal of International Cultural Studies, 23, 95-106.

Huang, M. (2015). A comparative study of Chinese and Japanese linguistic behavior in the closing section in agreement situation of invitational discourse: Focusing on two situations with different burden degrees. Japanese Language Education, 48/49, 22-31.

Ikoma, T., \& Shimura, A. (1993). Pragmatics transfer from English to Japanese: The speech act of refusals. Journal of Japanese Language Teaching, 79, 41-52.

Ito, E. (2002). Mareego bogowasha no chuukangengo ni mirareru goyouteki tokuchou: Kotowari hyougen ni okeru fuhensei to tokushusei (Ciri pragmatik yang ditemui dalam bahasa antara oleh penurut asli bahasa Melayu: Kesejagatan dan keistimewaan dalam ekspresi penolakan). Kotoba no Kagaku, 15, 179-197.

Kamus Dewan Edisi Keempat. (2007). Dewan Bahasa dan Pustaka.

Kamus Linguistik. (1997). Dewan Bahasa dan Pustaka.

Kasper, G., \& Rose, K. R. (2001). Pragmatics in language teaching. In K. R. Rose., \& G. Kasper (Ed.), Pragmatics in language teaching (pp. 1-9). Cambridge University Press.

Kawaguchi, Y., Kabaya, H., \& Sakamoto, M. (2002). "Invitation" as an "attitudinal expression". Waseda Journal of Japanese Applied Linguistics, 1, 21-30.

Laohaburanakit, K. (1995). Refusal in Japanese: A comparison of Japanese textbooks and actual conversation data. Journal of Japanese Language Teaching, 87, 25-39.

Leech, G. N. (1983). Principles of pragmatics. Longman. 
Liu, D. (2015). 'Kanyuu’ no gengo koudou ni tsuite no nitchuu taishou kenkyuu: Hikanyuusha no gengo koudou o chuushin to shite (Kajian kontrastif terhadap "ajakan" dalam bahasa Jepun dan Cina: Fokus kepada lakuan bahasa oleh pihak yang diajak (Tesis Dr. Falsafah tidak diterbitkan). Osaka University.

Mekkreangkrai, P. (2013). The differences in expressions of refusals between Japanese and Thai learners of Japanese: Focusing on the structure of refusals when using mobile e-mail. Japanese Language Education, 45, 11-19.

Miyake, K. (1994). Patterns of Japanese linguistic behaviour: Uchi, soto and yoso as a conceptual framework. Journal of Japanese Language Teaching, 9, 29-39.

Nakagaki, T. (2014). A comparative study of invitation in Japanese and Swahili: The case of declining an invitation to lunch. Nihongo \& Nihon Bunka Kenkyuu, 24, 170-185.

Nakagaki, T. (2015). A contrastive study of invitation in Japanese and Swahili: In the case of refusing the invitation to dinner. Journal of Swahili and African Studies, 26, 20-39.

Paramasivam, S. (2007). Managing disagreement while managing not to disagree: Polite disagreement in negotiation discourse. Journal of Intercultural Communication Research, 36(2), 91-116.

Shimizu, T. (2009). An introduction to interlanguage pragmatics. 3 anet.

The Japan Foundation. (2020). Survey Report on Japanese-Language Education Abroad 2018. The Japan Foundation.

Tsutsui, S. (2002). Kaiwa no kouzou bunseki to kaiwa kyouiku (Analisis struktur perbualan dan pendidikan perbualan). Studies in Japanese Language and Culture, 12, 9-21.

Usami, M. (2003). Cross-cultural contact and politeness from the viewpoint of Discourse Politeness Theory. Studies in the Japanese Language, 54(3), 117-132. 